\title{
Ordovician sponges from the Montgomery Limestone, Taylorsville area, northern Sierra Nevada, California, USA
}

\author{
J. Keith Rigby, Alfred W. Potter \& Nicolle K. Anderson
}

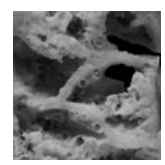

\begin{abstract}
The modest faunule of silicified fossil demosponges, documented here, was recovered from the Upper Ordovician Montgomery Limestone in the Taylorsville area, in the northern Sierra Nevada of northern California. Included are specimens of the ceractinomorph angullongiid Amblysiphonelloidea tubulara Rigby \& Potter, 1986, the girtyocoelliid Girtyocoeliana epiporata (Rigby \& Potter, 1986), the sebargasiid Amblysiphonella sp., and the cliefdenellids Cliefdenella alaskaensis Stock, 1981, and Rigbyetia obconica (Rigby \& Potter, 1986). In addition, specimens of the vaceletiid Corymbospongia adnata Rigby \& Potter, 1986, are described and figured. The assemblage is closely related to faunules of sphinctozoan sponges earlier reported by Rigby \& Potter (1986) from the eastern Klamath Mountains, to the west in northern California. - Key words: Ordovician, Montgomery Limestone, Sierra Nevada, California, Girtyocoeliana, Amblysiphonella, Cliefdenella, Rigbyetia, Corymbospongia.
\end{abstract}

Rigby, J.K., PotTer, A.W. \& Anderson, N.C. 2008. Ordovician sponges from the Montgomery Limestone, Taylorsville area, northern Sierra Nevada, California. Bulletin of Geosciences 83(3), 299-310 (5 figures). Czech Geological Survey, Prague. ISSN 1214-1119. Manuscript received June 27, 2008; accepted in revised form August 26, 2008; issued September 30, 2008.

J. Keith Rigby \& Nicolle K. Anderson, Earth Sciences Museum, Department of Geological Sciences, Brigham Young University, Provo, Utah 84602-4606; rigbyjkeith@gmail.com, nikki.anderson2@gmail.com・Alfred W.Potter, Daniel B. Stephens \& Associates, Inc., $461150^{\text {th }}$ Street, Lubbock, Texas 79414; apotter@dbstephens.com

Fossil sponges recovered from the Upper Ordovician Montgomery Limestone in the Taylorsville area of northern Sierra Nevada, California, are documented here. These fossils were collected by Vern McMath in 1955 and 1956 during his graduate research (McMath 1958) and deposited in the Natural History Museum of Los Angeles County, Los Angeles, California. They were later loaned to Alfred Potter, while he was a student at Oregon State University, and then sent to Rigby in 1988 by Lou Ella Saul from the Natural History Museum of Los Angeles County, Los Angeles, California.

The assemblage of sphinctozoans reported here and those documented by Rigby and Potter (1986) from the Eastern Klamath Mountains, both include specimens now included in the genera Amblysiphonella, Girtyocoeliana, Cliefdenella, Rigbyetia, and Corymbospongia. However, the diverse species of Imperatoria (now included in Pseudoimperatoria Senowbari-Daryan \& Rigby, 1988) reported from the Klamath Mountains are not represented in the suite of fossils described and figured here.

The fossils documented here were collected mostly from talus of the Montgomery Limestone of the Shoo Fly Complex, at Natural History Museum of Los Angeles County Locality LACMIP 24679 (Fig. 1), formerly Uni- versity of California, Los Angeles Locality 4679, in the Taylorsville area, in the northern Sierra Nevada Mountains, Plumas County, California. That locality is located at 2500 feet $(762 \mathrm{~m})$ east and 1800 feet $(549 \mathrm{~m})$ north of the southwest corner of Sec. 11, T. 25 N., R. 10 E., on the Greenville 15-minute topographic quadrangle (Figs 1,2). These talus occurrences are at an elevation of approximately 4100 feet, at the base of the cliff-forming limestone, on the south side of Montgomery Creek, a western tributary to Indian Creek, approximately 2.5 miles south of the community of Taylorsville. The lenticular units of the Montgomery Limestone were probably initially deposited in warm, shallow, normal marine water, in a low-energy forearc-forearc ridge environment prior to sliding down slope and becoming incorporated in a mélange.

Diller (1892) initially mapped the geology of the Taylorsville area and named the Montgomery Limestone for exposures of the lenticular limestone along Montgomery Creek. He later returned and further documented the geology of the extensive Taylorsville region (Diller 1908). Some time later McMath (1958) reinvestigated the geology of the Taylorsville area as part of his graduate degree work at the University of California, Los Angeles. 


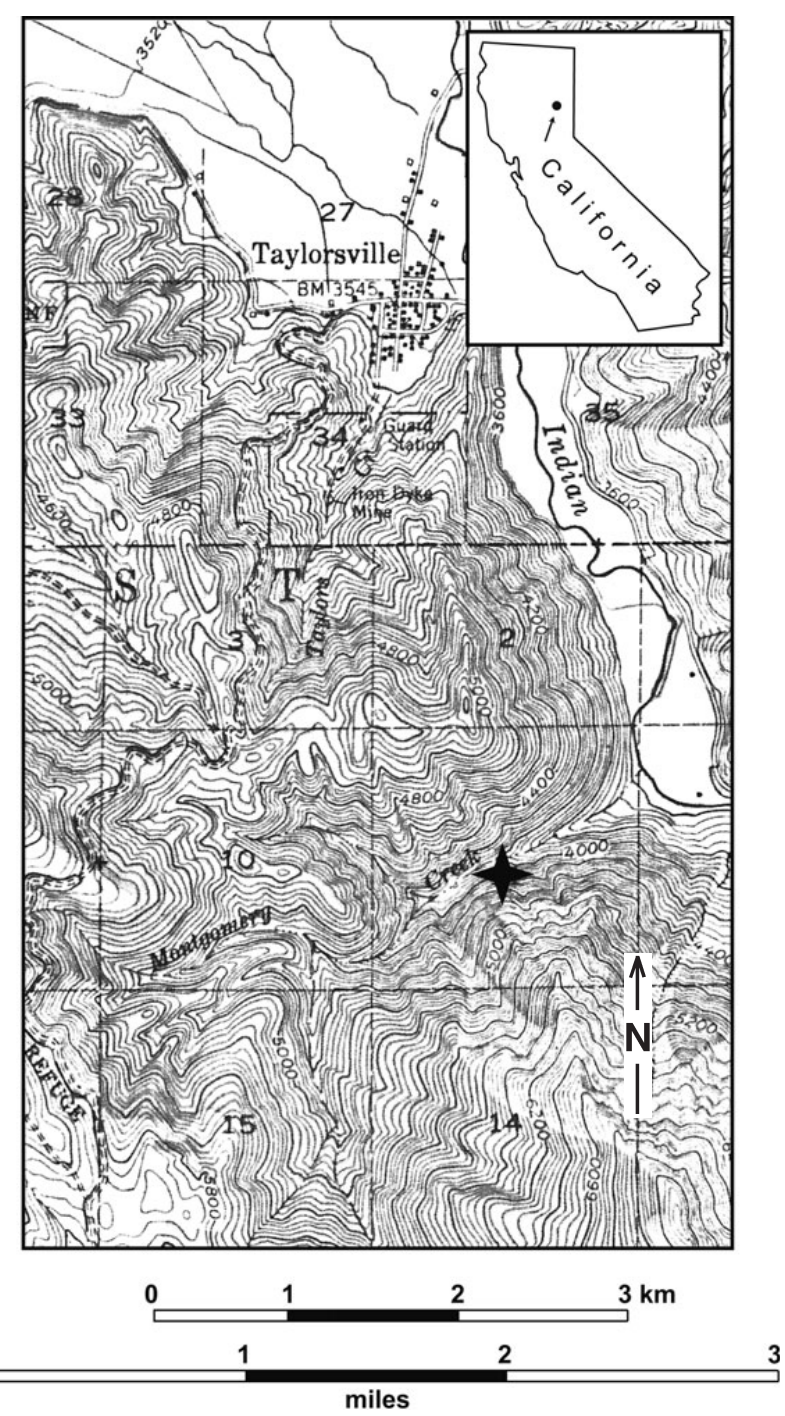

Figure 1. Index to Natural History Museum of Los Angeles County Locality LACMIP 24679, from which the sponges documented here were collected. The locality is along the south side of the canyon of Montgomery Creek, in the south-central part of Sec. 11, T. 25 N., R. 120 E., on the Greenville 15-minute quadrangle, Sierra Nevada, northern California. The inset map shows the general location of the locality in northern California.

\section{Systematic paleontology}

Class Demospongea Sollas, 1875

Subclass Ceractinomorpha Lévi, 1953

Order Agelasida Verrill, 1907

Family Angullongiidae Webby \& Rigby, 1985

Diagnosis. - "Cylindroid with central cloaca; superposed, toroidal chambers containing radial tubes or trabeculae; vesicles may be present; exopores small and numerous; endopores may be locally concentrated; ostia generally present at ends of mamelon-like protrusions; type genus has lamellar secondary lining to wall, but microstructure of primary wall not known..." (Finks \& Rigby 2004, p. 647).

\section{Genus Amblysiphonelloides Rigby \& Potter, 1986}

Type species. - Amblysiphonelloides tubulara Rigby \& Potter, 1986, pp. 19, 20, figs 7.6-7.12, 9.5.

Diagnosis. - "Moniliform sphinctozoans with chambers annular ring-like, with coarsely perforate walls; retrosiphonate central tube porous but finer than exterior walls. Chambers with straight, often ragged, tubes extending in from exopores, converging toward the endowall" (Rigby \& Potter 1986, p. 19).

\section{Amblysiphonelloides tubulara Rigby \& Potter, 1986 Figure 3A-D}

Type species. - Amblysiphonelloides tubulara Rigby \& Potter, 1986, pp. 19, 20, figs. 7.6-7.12, 9.5; Finks \& Rigby 2004, p. 677, figs 427-2a-d.

Diagnosis. - "Subcylindrical unbranched to proximally branched, cylindrical moniliform sphinctozoans made of ring-like chambers with coarsely perforate exowalls, interwalls, and endowalls; strongly retrosiphonate central tube is approximately one-third the diameter of the very uniformly annular-appearing sponge. Chambers regularly 2-3 mm high produce corrugated exterior. Irregular to ragged conical radial tubes extend from exopores in the central tubes. Walls distinctly and uniformly perforate" (Rigby \& Potter 1986, p. 19).

Description. - Three fragmental specimens of the species are well enough preserved to characterize the sponges included here. The largest of the three (Fig. 3A), NHMLA 13485 , is a moniliform fragment that is $22 \mathrm{~mm}$ tall, and includes 5 moderately complete chambers, with additional fragmental chambers at the top and bottom.

Chambers grade upward from a lower one, with a transverse section $7.5 \times 9 \mathrm{~mm}$ across, to the largest chamber, which $10 \times 13 \mathrm{~mm}$ across. Individual ringlike chambers commonly range from 2.0 to $2.5 \mathrm{~mm}$ tall, although a few range to $3.5 \mathrm{~mm}$ tall, and are separated by gently rounded indentations. Chamber exowalls are perforated by exopores that are $0.06-0.08 \mathrm{~mm}$ in diameter in the wall interior and $0.10-0.18 \mathrm{~mm}$ in diameter on the exterior, as locally preserved in the heavily silicified sponge. Where best preserved and most evident, these abundant pores are $0.10-0.20 \mathrm{~mm}$ apart in a moderately uniform, although not aligned, pattern. Chamber interwalls are perforated by interpores that range $0.2-0.4 \mathrm{~mm}$ in diameter, with most $0.2-0.3 \mathrm{~mm}$ in diameter and $0.3-0.5 \mathrm{~mm}$ apart, where locally preserved and exposed.

The central exhalant tube is cylindrical and approximately one-third the diameter of the upper chamber, where 
J. Keith Rigby et al. • Ordovician sponges from the Montgomery Limestone, California

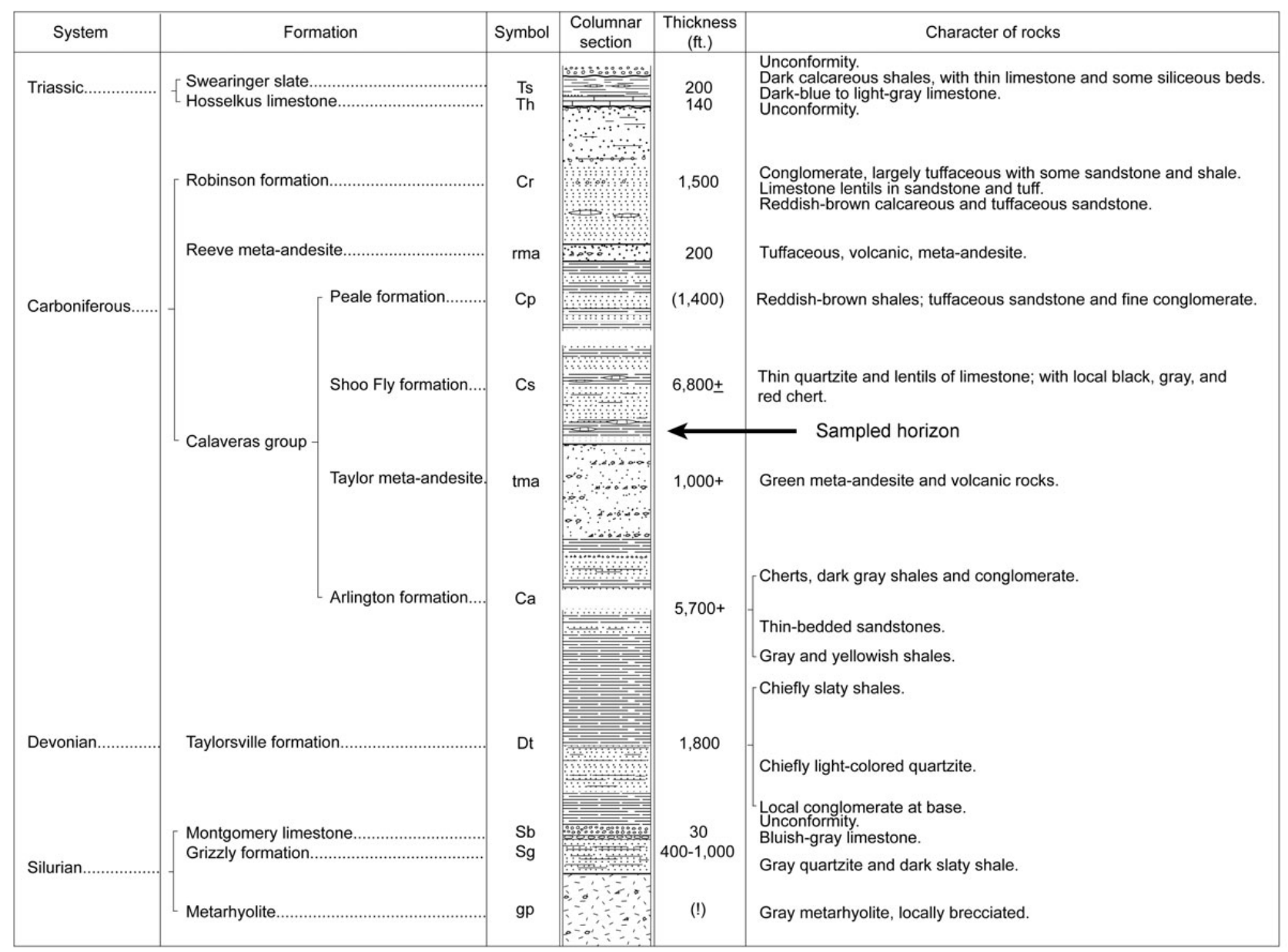

Figure 2. Stratigraphic section of Paleozoic rocks of the Taylorsville area showing the position of fossil locality LACMIP 24679, arrow, in the Montgomery Limestone of the Shoo Fly Complex (modified from Diller 1908).

it is exposed at the top of the fragment (Fig. 3B). It has walls $0.15-0.25 \mathrm{~mm}$ thick around the central opening, which is $6-7 \mathrm{~mm}$ in diameter. That wall, like much of the skeleton, is irregularly silicified so that only a few endopores are preserved. They are approximately $0.2 \mathrm{~mm}$ in diameter and are generally separated about $0.2 \mathrm{~mm}$.

The second instructive fragment of the species, NHMLA 13486 , is a short moniliform series of three moderately complete chambers and upper and lower chamber bits (Fig. 3C). It is $14 \mathrm{~mm}$ tall and has an ovoid transverse section $10 \times 14$ $\mathrm{mm}$ across. Individual chambers are 3.5-4 $\mathrm{mm}$ tall and are perforated by a central exhalant tube that is $6-7 \mathrm{~mm}$ across, with a central opening $4.0 \times 4.7 \mathrm{~mm}$.

Exopores in the outer wall are $0.1-0.2 \mathrm{~mm}$ in diameter, although an associated, possibly related exowall fragment has pores up to $0.5 \mathrm{~mm}$ in diameter. Endopores in the wall of the central tube are $0.1-3.5 \mathrm{~mm}$ in diameter and $0.2-0.35 \mathrm{~mm}$ apart in the $3-4$ rings of regularly stacked pores that occur per chamber, where exposed. Prominent interpores in the upper and lower walls between chambers range $0.16-0.25 \mathrm{~mm}$ in diameter, where circular, in the in- ner part of the wall, and range $0.4 \times 0.6 \mathrm{~mm}$ to $0.6 \times 0.8 \mathrm{~mm}$ across in ovate openings in the outer part. They are commonly separated $0.3-0.4 \mathrm{~mm}$ apart.

The third specimen, NHMLA 13487, is a short fragment of a relatively large-diameter specimen of the species (Fig. 3D). It has an ovate transverse section that is approximately $16 \times 19 \mathrm{~mm}$ across, and a central tube that is $4.5 \times$ $6 \mathrm{~mm}$ across. Interpores are locally exposed and are commonly $0.4-0.6 \mathrm{~mm}$ across, but locally larger ovate interpores range up to $0.6 \times 1.2 \mathrm{~mm}$ across. Their long lengths are parallel the long "diameter" of the ovate interpores. Exopores are locally exposed on part of the outer wall, and $0.3 \mathrm{~mm}$ in diameter to ovate pores $0.3 \times 0.6 \mathrm{~mm}$ across.

Material. - Three figured specimens, NHMLA 13485-13487, plus five moderate-sized specimens and four smaller skeletal fragments of the species are in the collection from LACMIP 24679.

Discussion. - Measurements and distributions of morphologic features of the two smaller figured specimens of $\mathrm{Am}$ - 
blysiphonelloides tubulara treated here fall within the general range of type material of the species reported from the eastern Klamath Mountains of northern California by Rigby \& Potter (1986, pp. 19, 20). Similar measurements are much larger in the associated larger-diameter sponge.

Chamber size, and other features of the specimens described here are considerably larger and coarser than those of Amblysiphonelloides reticulata Rigby \& Potter (1986, pp. 20,21), which was also reported from the Ordovician of the eastern Klamath Mountain, California.

\section{Family Girtyocoeliidae Finks \& Rigby, 2004}

Diagnosis. - "Spheroidal chambers; exowalls generally imperforate, with well-developed exauli, that may contain internal cribribulla, in equatorial ring; cloaca present except in juveniles (protocysts), with endopores often concentrated in a ring; filling structures sparse to absent, but vesicles or trabeculae may occur" (Finks \& Rigby 2004, p. 658).

\section{Genus Girtyocoeliana Rigby, Karl, Blodgett \& Baichtal, 2005}

Type species. - Girtyocoelia epiporata Rigby \& Potter, 1986, p. 39, figs. 8.1-9.4.

Diagnosis. - "Moniliform to branched stems of adnate, subspherical chambers that increase in size upward; exowalls imperforate except for large incurrent ostia at about midheight; chambers lack exaules; central tube prosiphonate(?). Prominent rimmed to tubular interpores in irregular ring around central tube. Small exopores in upper part of central tube in each chamber" (Rigby et al. 2005, p. 687).

\section{Girtyocoeliana epiporata (Rigby \& Potter, 1986)} Figure 4A-E, H

1986 Girtyocoelia epiporata Rigby \& Potter, 1986, p. 39, figs. 8.1-9.4.

2005 Girtyocoeliana epiporata (Rigby \& Potter, 1986). Rigby et al., 2005, pp. 867, 868, figs 3.1-3.4.

Diagnosis. - As for genus.

Description. - All three specimens of the species in the collection are multi-chambered, silicified forms. One of the best preserved, though silicified sponges of the species, NHMLA 13499, is a steeply obconical, monoserial, chambered form. It is approximately $26 \mathrm{~mm}$ tall and includes 7 more or less complete ovoid chambers and fragments of two additional small basal chambers. These lower chamber fragments are both approximately $2.0 \mathrm{~mm}$ tall and appear to increase upward from $2.2 \mathrm{~mm}$ up to $3.6 \mathrm{~mm}$ in diameter. Above them the next chamber is $3.6 \mathrm{~mm}$ in diameter and $3 \mathrm{~mm}$ tall. Chambers generally increase to largest elements near the middle of the sponge, where the largest chamber is $7 \mathrm{~mm}$ in diameter and $4 \mathrm{~mm}$ tall. The upper two normalappearing chambers are $6.4-6.5 \mathrm{~mm}$ in diameter and $3-5 \mathrm{~mm}$ tall. The uppermost, somewhat offset chamber is $4.5 \mathrm{~mm}$ in diameter and $2.0-2.2 \mathrm{~mm}$ tall.

The round summit is marked by a circular central osculum that is $1.0-1.1 \mathrm{~mm}$ in diameter. It is mostly filled with silicified debris, except for a small opening that leads down into the chamber. In some chambers at midheight, the chamber walls are locally interrupted so that the internal skeletal structure is locally evident. One of the better preserved and exposed axial exhalant tubes is approximately $0.6 \mathrm{~mm}$ in diameter, with silicified walls that are approximately $0.1 \mathrm{~mm}$ thick.

Interpores are preserved in the chamber summit wall around the axial tube. They are circular to ovate and range $0.2-0.4 \mathrm{~mm}$ in diameter or across. They are separated by skeletal elements irregularly only $0.05-0.1 \mathrm{~mm}$ wide.

Dermal chamber walls are approximately $0.3 \mathrm{~mm}$ thick, with an inner surface that is coated with radially convergent spinose silica. Such silica is probably secondary for the silicified main dermal layer does not show that structure, but is more massive. Locally, however, rare inhalant ostia are preserved as weak depressions that are $0.25-0.3 \mathrm{~mm}$ in diameter. Some of these have vaguely preserved thin walls $0.1-0.3 \mathrm{~mm}$ thick in the relatively massive-appearing silica replacements.

The shorter fragment of the three, NHMLA 13488, is associated with a partial stem of Rigbyetia obconica (Rigby \& Potter, 1986) (Figs 3E, 4F) and is the upper part of a curved moniliform stem that includes 4 chambers (Fig. 4C). These chambers increase in size irregularly upward, from $4 \mathrm{~mm}$ in diameter and $3 \mathrm{~mm}$ tall, in the lowest one, to $9 \mathrm{~mm}$ in diameter and $6 \mathrm{~mm}$ tall, in the uppermost one. A filled, round, central opening or osculum, $1.2 \times$ $1.5 \mathrm{~mm}$ across, is exposed in the interwall of the upper complete chamber (Fig. 4E). That opening or tube has an irregularly silicified wall $0.1-0.12 \mathrm{~mm}$ thick.

A few poorly preserved interpores are present in raggedly silicified interwalls exposed where the specimen was broken. Such interpores are also preserved as shallow, small rimmed depressions in the upper preserved interwall at the top of the fragment (Fig. 4E). These depressions suggest the presence of interpores 0.2 and $0.4 \mathrm{~mm}$ in diameter.

Chamber walls are generally imperforate in their silicified replacements, but a few inhalant ostia are preserved at about midheight in the exowalls of upper chambers 


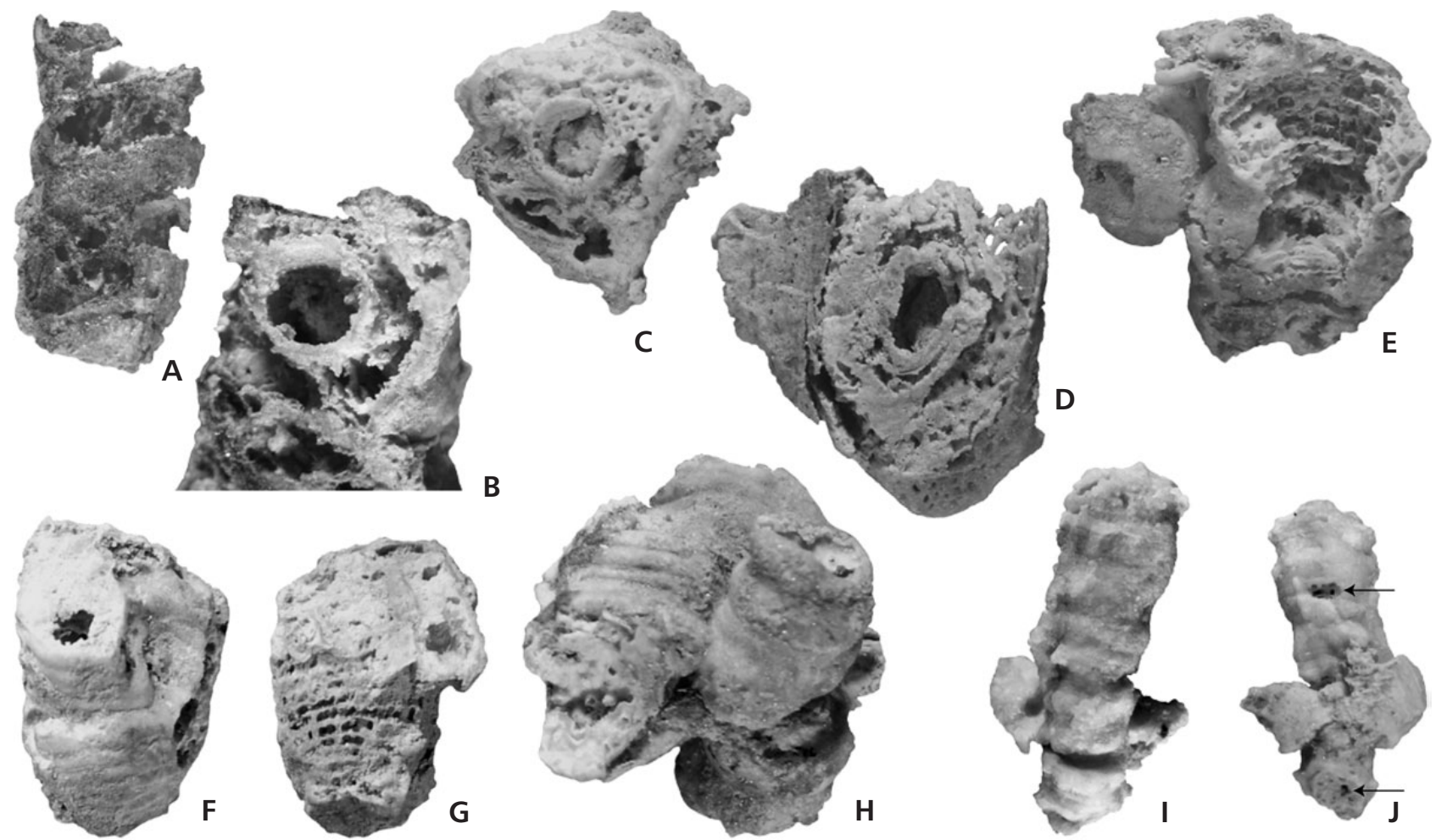

Figure 3. Photographic figures of specimens of Amblysiphonelloidea, Girtyocoeliana, Amblysiphonella and Rigbyetia from the Ordovician Montgomery Limestone, of Locality LACMIP 24679, northern California. • A-D - Amblysiphonelloidea tubulara Rigby \& Potter, 1986. • A, B - NHMLA 13485; - A - side view of moniliform fragment showing gradual upward increase in dimensions of chambers, and their ring-like shapes, with coarsely porous exowalls, $\times 2.2$. $\bullet \mathrm{B}-$ view of upper end of sponge showing the thick-walled, central exhalant tube, with a few coarse endopores, $\times 3.3$. $\bullet$ C - NHMLA 13486, side view of smaller fragment with three nearly complete middle chambers, which have tips of the central exhalant tube exposed in the top and the bottom of the sponge, $\times 2.2 . \cdot \mathrm{D}-$ NHMLA 13487 , short fragment of the species with ovate transverse section showing the central exhalant tube and the long diameter interpores, $\times 5.6$. E-J - Rigbyetia obconica (Rigby \& Potter, 1986), NHMLA 13493-13495. $\bullet$ E - larger and better preserved fragment of the species, NHMLA 13493, side view of fragment showing upward expansion of the skeleton, from lower chambers, where the dermal surface is marked with their low, ringlike annulations, to broken upper chambers, where sections show the stacked skeletal structure, with basal view of associated Girtyocoeliana epiporata (Rigby \& Potter, 1985) shown on the left, $\times 2.2$. $\bullet \mathrm{F}, \mathrm{G}-$ smaller steeply obconical fragment, NHMLA 13494. $\bullet \mathrm{F}-$ side view showing growth form and interior skeletal structure, where dermal wall locally removed, $\times 5.6 \cdot \bullet \mathrm{G}-$ side view of lower area where dermal wall has been removed and horizontal chambers and thin-walled vertical tubules show, $\times 5.6 \cdot \bullet \mathrm{H}-$ diagonal view up into lower part of sponge, showing transverse basal section with central oscular tube, and several other smaller tubular openings in chamber interwall, and above that the side view where perforate chamber interwalls and associated tubules are exposed, $\times 2.2$. $\bullet$ I, J - NHMLA 13495; I -side view of near-basal small subcylindrical specimen with only moderately well-defined chambers; $\times 5.6 . \bullet \mathrm{J}-$ specimen with interior structure locally exposed where dermal layer has been eroded; diagonal view of lower part of sponge shows the moderate central exhalant canal in the base and surrounding pores of smaller tubules; a small opening through the dermal layer in upper part exposes bits of the fine tubular interior structure, $\times 5.6$.

(Fig. 4H). Some of these ostia are irregular openings approximately $0.6-0.7 \mathrm{~mm}$ in diameter, and others are defined by faint rimmed depressions in the silicified wall. A few openings have rims to $0.3-0.4 \mathrm{~mm}$ thick that rise up to $0.1 \mathrm{~mm}$ from the dermal surface.

The more or less complete specimen of the species with the larger diameter, NHMLA 13489, is partially imbedded in matrix and includes 7 nearly complete ovoid chambers and fragments of two small, near-basal chambers (Fig. 4A). Chambers increase somewhat irregularly in height and diameter, from near-basal chamber fragments 2.0-3.2 $\mathrm{mm}$ in diameter and approximately $1.5 \mathrm{~mm}$ high, up to upper chambers that are to $6.3-6.4 \mathrm{~mm}$ in diameter and 3.9-4.5 mm high. The uppermost chamber, however, is only $4.2 \mathrm{~mm}$ in diameter and $2.2 \mathrm{~mm}$ high. Chamber walls also increase in thickness upwards, from midchamber thicknesses of $0.25-0.30 \mathrm{~mm}$ in lower chambers to approximately $0.6 \mathrm{~mm}$ thick in upper chambers.

The rounded summit of the upper chamber is pierced by a central circular osculum, $1.8 \mathrm{~mm}$ in diameter (Fig. 4B), which grades downward into the retrosiphonate central tube that is up to $1.2 \mathrm{~mm}$ in diameter and has walls $0.2 \mathrm{~mm}$ thick in the upper chamber. There and in lower chambers, that tube surrounds an open spongocoel that is $0.6-0.8 \mathrm{~mm}$ in diameter, and is visible in broken segments through the fractured chamber walls of the fourth and fifth chambers from the bottom. Here sections of that spongocoel are also approximately $0.8 \mathrm{~mm}$ in diameter, where its walls are parts of porous interwalls between chambers. 
Interpores are locally preserved as short tubular perforations or rimmed pores in the interwalls around the central tube (Fig. 4B). Where most evident in one of the middle chambers, before the fragments were glued together, these pores are approximately $0.25-0.30 \mathrm{~mm}$ in diameter and have thin, locally preserved, tubular walls up to $0.1 \mathrm{~mm}$ tall, or ridge-like rims $0.15 \mathrm{~mm}$ thick and high around each openings. Only a few such rims or tubes are preserved, but their positions suggest perhaps as many as $6-8$ such openings may have been present in each chamber interwall.

Inhalant ostia like those present in typical material are not preserved in the moderately coarsely crystalline silicified chamber exowalls. Faint depressions, 0.3-0.5 $\mathrm{mm}$ in diameter, are locally developed or preserved in the outer surface of the chamber walls, but they are all filled in with silica like the rest of the wall.

Material. - Three silicified figured specimens of the species, NHMLA 13488, 13489, and 13499, are in the collection from Locality LACMIP 24679.

Discussion. - The larger of the fragmental specimens of the species has skeletal elements somewhat coarser, or larger, than those of the type specimens (Rigby \& Potter 1986, p. 39; Rigby et al. 2005, pp. 687, 688). However, because of the similarity of form and structure of the sponges, and because of their similar geologic and geographic relationships, we have included these larger sponges, along with the smaller diameter, more-nearly complete NHMLA 13499 , in that earlier described species.

Family Sebargasiidae de Laubenfels, 1955

Diagnosis. - "Cylindroid; central cloaca (retrosiphonate); small, circular, closely spaced exopores; wall microstructure spherulitic; no spicules known; vesicles may be present in chambers but not pillars or trabeculae" (Finks \& Rigby 2004, p. 675).

\section{Genus Amblysiphonella Steinmann, 1882}

Type species. - Amblysiphonella barroisi Steinmann, 1882 , p. 170.

Diagnosis. - Cylindrical, sometimes subparallel branched segments correspond externally to interior chambers that are in linear series; central cloaca about one-third sponge diameter; exowall with numerous small, circular, closely spaced expores; interwall a continuation of exowall, below, with similar pores; endowall somewhat thinner and endopores somewhat larger and more widely spaced; interior of chamber and sometimes cloaca may contain imperforate vesicles; wall micro- structure small, isodiameteric spherulites that may expand asymmetrically into lumens of pore canals and chambers; no spicules known..." (Finks \& Rigby 2004, p. 677).

\section{Amblysiphonella sp.}

Figure 4G

Description. - The better specimen of the species, NHMLA 13490, is a diagonally cut, moniliform, stem fragment that is $20 \mathrm{~mm}$ tall (Fig. 4G). It consists of parts of six ring-like chambers that are $2-3 \mathrm{~mm}$ high and $8-10 \mathrm{~mm}$ in diameter. Chambers are $4 \mathrm{~mm}$ wide and surround a retrosiphonate central tube that is approximately $2 \mathrm{~mm}$ in diameter in the main body, but widens up to approximately $2.5 \mathrm{~mm}$ at the preserved summit. Chamber walls curve outward from basal sutures, then arch upward and inward to form chamber interwalls that curve downward to meet the more or less cylindrical endowalls of the central tube. These walls are approximately $0.4 \mathrm{~mm}$ thick, as silicified. Rare scattered vesiculae, up to $1 \mathrm{~mm}$ across, are evident in sections near the central tube.

Skeletal elements are replaced with relatively massive silica, although locally some pores are preserved. Exhalant pores in the central tube are circular to ovoid and slightly elongate, vertically. The few that are preserved are $0.2-0.3 \mathrm{~mm}$ in diameter (Fig. 4G), and are separated by about the same distance. Interpores between chambers and in exowalls are also locally preserved and range $0.08-0.10 \mathrm{~mm}$ in diameter. They are separated, particularly on interior surfaces, by prominent, small, spinose-appearing, secondary quartz crystals that are up to $0.3 \mathrm{~mm}$ long and radiate into the chambers from the walls.

Another small moniliform fragment of the species, NHMLA 13491, is not figured but consists of parts of four chambers that have been vertically bisected along the central tube. These chamber remnants are approximately $2 \mathrm{~mm}$ tall, $6 \mathrm{~mm}$ in diameter, and border on the margin of a central tube that is approximately $1.5 \mathrm{~mm}$ wide. It has also been replaced with silica and the probable pores of the skeleton have been destroyed in the process.

Material. - Two fragmental specimens of the species, including the figured specimen NHMLA 13490 and the unfigured NHMLA 13491, are included in the studied collection from Locality LACMIP 24679.

Discussion. - Specific identification of the two fragments is impossible because of their incompleteness and massive silicification, which has destroyed most of their fine skeletal characteristics. The sponges documented here are considerably smaller than representatives of Amblysiphonella grossa Rigby \& Potter (1986, pp. 15-19) described from Ordovician rocks of the eastern Klamath Mountains of northern California. 

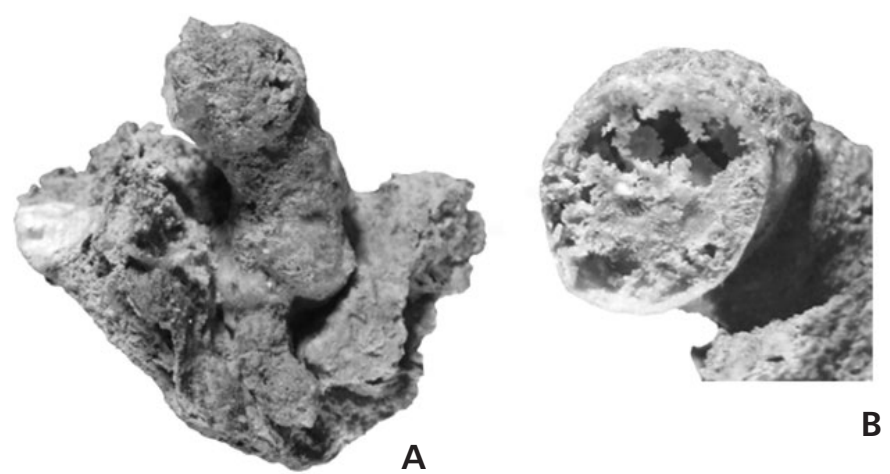

B
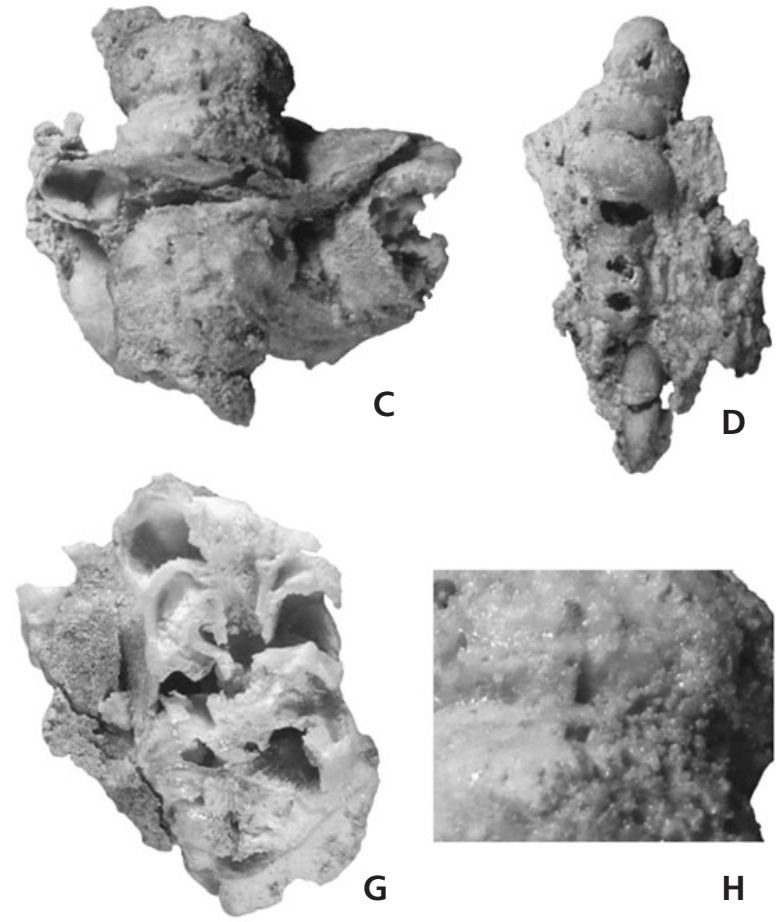



E



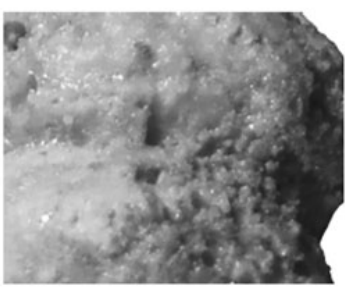

H

Figure 4. A-E, H - Girtyocoeliana epiporata (Rigby \& Potter, 1986). A, B - NHMLA 13488; A - side view of taller, larger-diameter specimen of the species includes seven nearly complete chambers and upper and basal fragments; chambers increase irregularly in size and thickness upwards, to here central osculum is exposed in porous interwall of upper chamber, $\times 2.2$. $\bullet$ B - interpores show as shallow, rimmed, depressions in upper interwall at top of sponge, hidden behind the top chamber of Fig. 4A, $\times 5.6 \cdot \bullet \mathrm{C}, \mathrm{E}, \mathrm{F}, \mathrm{H}-$ shorter of three specimens of the species, NHMLA $13488 . \bullet \mathrm{C}-$ side view with principal chambers partially buried in matrix, but with ovoid chambers increasing in size and wall thicknesses upward, $\times 2.2$. $\bullet \mathrm{H}-$ detail of nodular dermal surface with a few inhalant ostia in exowalls of two upper chambers, $\times 10 . \cdot$ D - NHMLA 13499 , side view of steeply obconical, nearly complete, sponge with small fragments of two basal chambers, largest chambers near mid-height, and smaller, offset, chamber at summit; rare inhalant ostia are preserved in silicified upper dermal layer, and internal structure exposed at midheight in gaps fractured chamber walls, $\times 2.2$. $\bullet E-$ rounded upper summit with central osculum that grades downward to central tube; small rimmed interpores are most evident in the upper part of the interwall, $\times 5.6$. $\bullet \mathrm{F}-$ transverse section of base of ovoid sponge shown in Fig. 4C, with small rimmed interpores evident in the middle of the interwall, a side view of small Rigbyetia obconica whose dermal surface is marked with distinct annulations is shown on the left, $\times 5.6 . \bullet \mathrm{G}-$ Amblysiphonella sp., NHMLA 13490 ; diagonally-cut moniliform series of 6 chambers around a retrosiphonate central tube that widens slightly upward to the preserved summit; basal chamber walls curve outwards and upwards and then curve to meet the cylindrical walls of the central tube, $\times 5.6$.

\section{Family Cliefdenellidae Webby, 1969}

Diagnosis. - "Sphinctozoans with low, flat to convex-upward chambers with imperforate walls; interwalls penetrated by continuous, subvertical, porous, pillarlike tubes; complex astrorhizae-like, clustered, excurrent, canal system separate from pillarlike incurrent system and occurring between thin, imperforate walls; skeletons of aspicular calcium carbonate" (Finks \& Rigby 2004, p. 681).

\section{Genus Cliefdenella Webby, 1969}

Type species. - Cliefdenella etheridgei Webby, 1969, p. 655.

Diagnosis. - "Sphinctozoan sponges composed of low, platelike, hollow chambers with imperforate interwalls pierced by porous, vertical, pillarlike tubes produced by downward deflection of interwall in retrosiphonate-like, incurrent, canal system; excurrent system of astrorhizal-like canals that converge laterally from chambers and curve vertically into clusters of subvertical, tubelike openings; vertical incurrent and excurrent tubes not interconnected; vesiculae may occur in early chambers, vertical, porous, incurrent tubes, and in excurrent canals interwalls may be three layered, with lower and upper, clear layers separated by a medial, dark layer; upper surface commonly denticulate" (Finks \& Rigby 2004, p. 681).

Discussion. - Cliefdenella contrasts with Rigbyetia Webby \& Lin (1988, p. 152) in being more irregularly massive and hemispherical rather than steeply obconical to subcylindrical in general form, and in having multiple excurrent canal systems in contrast to the single central system in Rigbyetia. Cliefdenella also contrasts with Khalfinaea Webby \& Lin (1988, pp. 152, 153) in lacking a clearly defined endowall around the central single "excurrent" central tube. 


\section{Cliefdenella alaskaensis Stock, 1981 \\ Figure 5A-E}

1981 Cliefdenella alaskaensis Stock, pp. 1000-1004, Pl. 1, figs $1-8$

Diagnosis. - "Sheetlike laminae spaced $4.5-10.5$ per $5 \mathrm{~mm}$, $0.05-0.20 \mathrm{~mm}$ thick, separated by galleries $0.25-1.33 \mathrm{~mm}$ high. Long (up to $19.42 \mathrm{~mm}$ ) tube-pillars spaced 2.0-8.0 per $5 \mathrm{~mm}, 0.25-0.60 \mathrm{~mm}$ in diameter, $0.38-1.13 \mathrm{~mm}$ apart. Tube-pillar walls $0.05-0.11 \mathrm{~mm}$ thick. Cyst-plates in tube-pillars spaced $1.5-7.0$ per $\mathrm{mm}$. Up to 28 canals in astrorhizal columms" (Stock 1981, p. 1000).

Description. - A single large silicified sponge of the species, NHMLA 13492, is in the collection. It apparently is now broken into four moderately large and five small fragments. From what can be concluded from those pieces (Fig. 5A-E), the sponge was originally obconical, approximately $45 \mathrm{~mm}$ tall (Fig. 5A, B) and expanded upward from a near-basal 11 $\mathrm{mm}$ in diameter (Fig. 5E) to $45 \mathrm{~mm}$ thick and $51 \mathrm{~mm}$ wide near the upward arcuate, bimodal or trimodal, summit. Its skeleton is composed of numerous, low, flat to irregularly upward arcuate chambers defined by transverse, thin interwalls. These chambers are mostly approximately $1.0 \mathrm{~mm}$ high, but range $0.8-1.2 \mathrm{~mm}$ high, and rarely pinch out laterally in the interior. Interwalls flex sharply downward and grade into the exowalls at the dermal margins.

Sheetlike interwalls are approximately $0.1 \mathrm{~mm}$ thick, and are pierced by numerous vertical, pillar-like, porous tubules (Fig. 5C). These tubules are spaced from 0.2-0.3 to $1 \mathrm{~mm}$ apart. Most are separated, wall to wall, about $0.5 \mathrm{~mm}$ apart. Segments of the tubules were added chamber by chamber during growth. Individual segments expand upward from a narrower base, at the perforation through the previous interwall, and then flare laterally at the top of the segment to merge with the overlying interwall. These segments merged to form continuous tubules that originated in the lower part of the skeleton and then diverged upward. New tubules originated in the open spaces. Tubule segments widen from $0.4-0.5 \mathrm{~mm}$ in diameter to flare to $0.5-0.7 \mathrm{~mm}$ where they merge with the overlying interwall, and new tubule segments were inserted in the series. Tubules are smallest near the dermal area, where they were initiated. Some tubules, with ovate transverse sections $0.5 \times 0.7 \mathrm{~mm}$ across, branched into two side-by-side tubules approximately $0.5 \mathrm{~mm}$ in diameter. These tubules are perforated by small pores, $0.04-0.08 \mathrm{~mm}$ in diameter, which pierce the tubule walls that are $0.2-0.4 \mathrm{~mm}$ thick, and thicken upward in each segment.

Upper surfaces of interwalls are micronodose (Fig. 5D), with abundant nodes $0.15-0.35 \mathrm{~mm}$ in diameter that are up to approximately $0.2 \mathrm{~mm}$ tall. They are virtually side-by-side and cover the interwalls between the walls of the vertical tu- bules. Lower surfaces of interwalls are also micronodose in the silicified preservation, but these nodes are only approximately $0.02 \mathrm{~mm}$ in diameter. They may be only secondary and produced by the small spherulites of the silicified skeleton.

Material. - The single specimen, NHMLA 13492, now composed of two large fragments, three moderate-sized fragments, and four small fragments of the silicified sponge, represent the genus and species in the collection from Locality LACMIP 24679.

Discussion. - The fragments included here are only part of a larger sponge whose original growth size is unknown. The type specimens documented by Stock (1981, p. 1000, pl. 8, figs 1-8) are also fragments, which also show the internal skeletal and gallery structure, but not the size of the complete sponge.

\section{Genus Rigbyetia Webby \& Lin, 1988}

Type species. - Cliefdenella obconica Rigby \& Potter, 1986, pp. 42-44.

Diagnosis. - "Obconical to subcylindrical, occasionally branching, aporate sphinctozoan; chambers of low, ringlike, annulated appearance with imperforate exowalls; laminate, gently domed, imperforate interwalls with upper surface denticulate and locally downwardly inflected into vertical to subvertical, porous, incurrent tubes, internally; single, large, central tube of vertically continuous clusters of astrorhizal-like, excurrent canals; this seemingly interconnected with radiating nearly horizontal, astrorhizal canals of chambers, no clearly defined endowall or endopores developed; vesiculae small and only rare in chambers, not developed elsewhere; hollow, rootlike, bracing structure may be developed" (Finks \& Rigby 2004, p. 683).

Discussion. - Specimens of the genus, as defined by Webby \& Lin (1988, p. 152), have been reported from Upper Ordovician rocks of the Klamath Mountains of northern California (Rigby \& Potter 1986, p. 42), and from the Upper Ordovician Malongulli Formation of central-western New South Wales, Australia (Webby \& Morris 1976, p. 128; Webby 1986, p. 158). The specimens documented here, from Ordovician rocks of the northern Sierra Nevada, in Northern California, add to the known distribution of the genus and species.

Rigbyetia obconica (Rigby \& Potter, 1986) Figure 3E-J

1986 Cliefdenella obconica Rigby \& Potter, 1986, pp. 42-44, figs 11.6-11.8. 

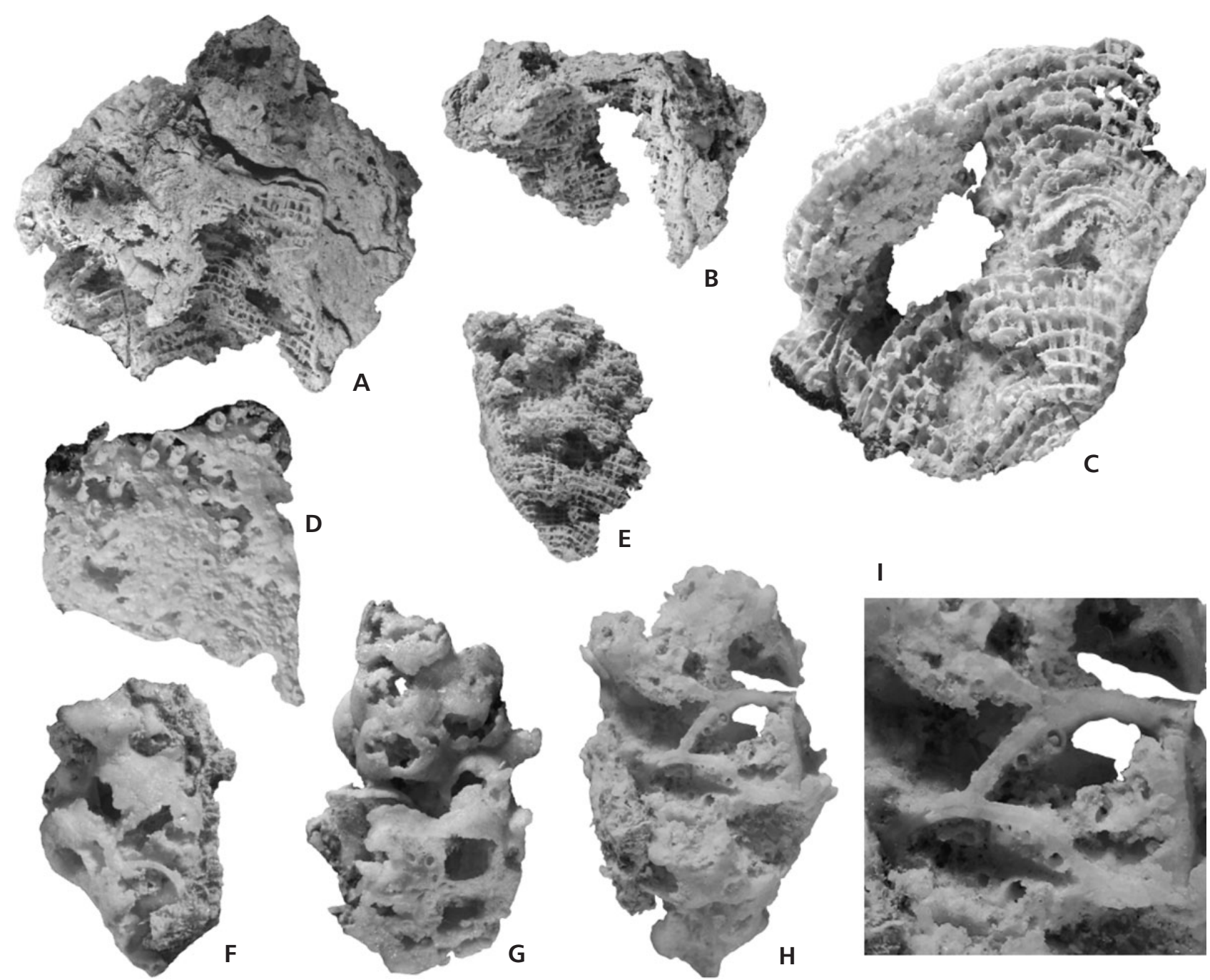

I

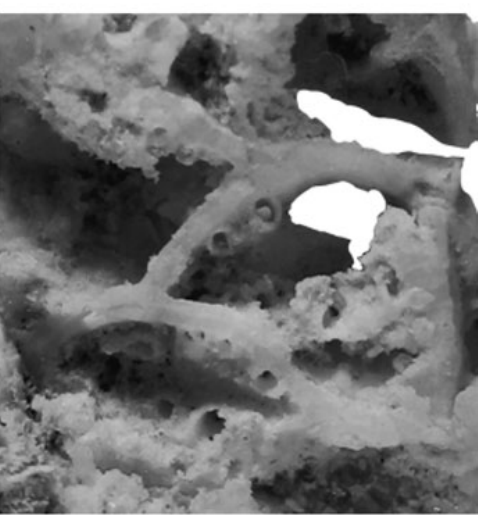

Figure 5. Photographic figures of specimens of Cliefdenella and Corymbospongia from the Ordovician Montgomery Limestone, of Locality LACMIP 24679, northern California. • A-E - Cliefdenella alaskaensis Stock, 1981, NHMLA 13492. • A - summit and largest part of fractured silicified figured specimen, $\times 1$. $\bullet \mathrm{B}-$ other part of summit region that joins with the fragment shown in Fig. 5A. $\bullet \mathrm{C}-$ near-basal fragment of the large sponge shows the prominent vertical tubules and the thin arcuate transverse interwalls, $\times 5 . \bullet \mathrm{D}$ - small fragment of an interwall of the figured specimen, as seen from above, showing pores and tubules through interwalls, $\times 3$. $\bullet$ E - side view of near-basal fragment of the large sponge, $\times 1$. $\bullet$ - I - Corymbospongia adnata Rigby \& Potter, 1986, figured specimens, NHMLA 13496-13498. $\bullet$ F - NHMLA 13498; side view of small cluster showing a pair of chambers inter-connected by exaules, and other arcuate chambers with interpores in interior walls, $\times 2 . \bullet \mathrm{G}-$ NHMLA 13496 ; figured specimen, tall cluster of adnate to fused chambers, some of which have isolated elongate exaules and others are cut diagonally so that interpores show in some wall, $\times 2$. $\bullet$ H, I - NHMLA 13497; figured fragment of lower part of chamber cluster, with upward arcuate adnate chambers. $\bullet \mathrm{H}$ - side view of cluster showing nature of dense dermal layer and porous interlayers of chambers perforated by interpores in cluster interior, $\times 2 . \bullet I-$ photomicrograph of porous interwalls of several adjacent chambers where interpores are well exposed, $\times 5$.

1988 Rigbyetia obconica (Rigby \& Potter, 1986). - Webby \& Lin, 1988, p. 152; Finks \& Rigby, 2004, p. 683, fig. 453a-d.

Diagnosis. - "Conical-subcylindrical to steeply obconical sphinctozoan sponges made of low laminar chambers around a cluster of excurrent canals; chamber walls and interwalls imperforate to locally perforate with denticulate upper surfaces; interwalls pierced by numerous subvertical, porous, tubular canals produced by retrosiphonate-like downward flexing of chamber floors or interwalls. Hollow root-like bracing structures may occur in the low exterior" (Rigby \& Potter 1986, p. 42).

Description. - The larger and better preserved fragment, NHMLA 13493, is associated with a smaller fragment of the species and other sponges, and is a somewhat oblique vertical section through the steeply obconical specimen. That fragment (Fig. 3E) is approximately $26 \mathrm{~mm}$ tall, and expands upward from the preserved fragmented base, 
$7 \mathrm{~mm}$ in diameter, to the summit that is $15 \mathrm{~mm}$ in diameter. The dermal surface is marked by low ring-like annulations of chambers that are $0.8-1.5 \mathrm{~mm}$ high and separated by shallow indentations.

The vertical section of the upper interior (Fig. 3E) shows gently upward-arcuate chambers $1.0-1.2 \mathrm{~mm}$ high, separated by interwalls approximately $0.1 \mathrm{~mm}$ thick. A poorly defined, ragged-appearing, central opening is approximately $1.5 \mathrm{~mm}$ in diameter, where best defined in the lower part of the sponge.

The characteristic vertical, small, walled tubules show well in the lower part of the fragment base (Fig. 3H) and are approximately $0.4-0.5 \mathrm{~mm}$ in diameter near the outer wall, but are somewhat larger, up to $0.6-0.7 \mathrm{~mm}$, with the central openings approximately $0.5 \mathrm{~mm}$ in diameter, where most tubules are larger in the central part of each chamber. They have porous wall, with pores $0.025-0.03 \mathrm{~mm}$ in diameter and $0.1-0.2 \mathrm{~mm}$ apart. These tubules are 0.4-0.6 $\mathrm{mm}$ apart in upper parts of the sponge, but are separated by common smaller pores $0.3 \mathrm{~mm}$ in diameter, with central pores $0.15 \mathrm{~mm}$ in diameter, which pierce the chamber interwalls.

The associated smaller specimen is a vertical partial section, $15 \mathrm{~mm}$ tall and with an upper width of $15 \mathrm{~mm}$, through the upper part of a sponge. It shows the internal structure of the species, where upward-arcuate chambers and vertical tubules are like those of the associated specimen of the species.

Another specimen of the species, NHMLA 13494, is approximately $16 \mathrm{~mm}$ tall and shows the characteristic annulate dermal surface to the steeply obconical fragment (Fig. 3F) and the arcuate chambers in the interior of a small area where the dermal layer has not been preserved (Fig. 3G). The eroded circular base is approximately $7 \mathrm{~mm}$ in diameter and the sponge expands upward for $15 \mathrm{~mm}$. At that point diverge two adhering branches of another smaller, but unidentifiable genus. The upper part of one of those branches is obscured in matrix, but the other branch is traceable for an additional $7 \mathrm{~mm}$, to where an irregular cross section, $9 \mathrm{~mm}$ wide, is exposed at the broken summit. Arcuate chamber sections in this adnate sponge, there, are $1.0-1.5 \mathrm{~mm}$ high, with chamber interwalls approximately $0.10-0.12 \mathrm{~mm}$ thick. Vertical tubules, $0.4-0.7 \mathrm{~mm}$ in diameter, have porous walls and interconnect the stacked chambers.

An isolated small, near-basal specimen of Rigbyetia obconica, NHMLA 13495 (Fig. 3I, J), is approximately $24 \mathrm{~mm}$ tall, and expands upward from a broken near-basal diameter of $4 \mathrm{~mm}$ to $7.5 \mathrm{~mm}$ at the preserved summit. Chambers are approximately $0.5 \mathrm{~mm}$ tall and are separated by interwalls $0.04 \mathrm{~mm}$ thick, as suggested by traces in the silicified specimen, and indentations between the stacked chambers. Parts of the arcuate chambers, their thin interwalls, and the vertical tubules are ex- posed in two small areas on the sponge where the outer wall has been breached (Fig. 3J, upper arrow). The tubules are approximately $0.5 \mathrm{~mm}$ in diameter, and have central openings $0.3-0.4 \mathrm{~mm}$ in diameter where exposed in the broken base of the sponge. A central exhalant canal is suggested by a ragged opening $0.5-0.6 \mathrm{~mm}$ in diameter in the base of the specimen (Fig. 3J, lower arrow).

Material. - Three moderately large figured specimens, NHMLA 13493-13495, and seven other smaller fragments are in the collection from Locality LACMIP 24679, from the Montgomery Limestone in the Taylorsville area of northern California, a locality noted by Elias et al. (1944). Except for the co-occurrence of one of these specimens with a stem of Girtyocoeliana epiporata (Rigby \& Potter, 1986), in a single rock fragment, they are associated with common, mostly small, unidentifiable skeletal elements of other fossils.

Discussion. - The co-occurrence of several specimens, as fragments with a nearly complete specimen of Girtyocoeliana in a silicified specimen suggests these are part of sponge species from the Taylorsville locality. Other similar pieces suggest the same. The small figured specimen, NHMLA 13495, and its associated tan fragments, lack the organic coloration and are differently preserved, although also silicified, and must have been from a different area or layer at Locality LACMIP 24679.

Order Vaceletida Finks \& Rigby, 2004

Family Colospongiidae Senowbari-Daryan, 1990

Diagnosis. - Porate, thalamid sponges without a central canal or spongocoel and without filling structures; pores of segments unbranched or with only dichotomous branches; basal skeleton primarily aragonitic" (Finks \& Rigby 2004, p. 697).

Subfamily Corymbospongiinae Senowbari-Daryan, 1990

Diagnosis. - "Glomerate to stratiform arrangement of chambers" (Finks \& Rigby 2004, p. 701).

\section{Genus Corymbospongia Rigby \& Potter, 1986}

Type species. - Corymbospongia adnata Rigby \& Potter, 1986, pp. 28, 29.

Diagnosis. - "Clusters of spheroidal to ellipsoidal chambers, possibly encrusting; each chamber bearing long exaulos often arising from a mamelon-like protuberance; exauli 
of cluster tend to face same direction (possibly upward); chamber walls perforated by small, circular pores that bear lips on inner wall of chamber; adjacent chambers may communicate by these pores but not by exauli; no internal structures except possibly vesicles; microstructure not known; no spicules known” (Finks \& Rigby 2004, pp. 701, 702).

\section{Corymbospongia adnata Rigby \& Potter, 1986} Figure 5F-I

1986 Corymbospongia adnata Rigby \& Potter, pp. 28, 29, figs 10.1-10.6; Rigby et al., p. 865, figs 3.7, 3.10, 3.11 .

Diagnosis. - General form as in genus with perforate chambers 3-8 $\mathrm{mm}$ in diameter, mostly $4-5 \mathrm{~mm}$ in diameter where circular and $3 \times 5$ to $4 \times 8 \mathrm{~mm}$ across where oval; imperforate prominent exaules extend from mound-like base up to $2.5 \mathrm{~mm}$ in diameter. Exaules abruptly narrow to subcylindrical tubes $1.0-1.5 \mathrm{~mm}$ in diameter (modified from Rigby \& Potter 1986, p. 28).

Description. - Irregular silicified fragments of the species in the collection range from small fused pieces of a few chamber walls, to broken clusters, up to $10-15 \mathrm{~mm}$ wide and $35 \mathrm{~mm}$ tall, of many adnate, irregularly oriented and spaced chambers (Fig. 5F-I). A few specimens have associated, but somewhat isolated chambers. Chamber clusters lack a central tube or spongocoel.

Individual chambers in the fragments, such as in NHMLA 13496, are commonly adnate and arcuate or irregularly ovoid. They may range from funnel-like and elongate to spheroidal elements, where separated, or to attached, mutually overgrown elements where in contact. The latter are dominant chambers in earlier parts of the sponges. Such chambers in the larger fragments include irregularly oriented and spaced, overlapping to arcuate chambers with multiperforate walls. Some chambers share narrow necklike junctions where two or more chambers are joined (Fig. 5F).

Individual chambers are commonly 4-5 mm wide, or in diameter, normal to their length, and may be up to $6-8 \mathrm{~mm}$ tall, beyond which extend their terminal tubular exaules. Chambers commonly have thin walls, $1.1-1.3 \mathrm{~mm}$ thick, perforated by scattered to isolated interpores $0.1-0.2$ to 0.4-0.5 mm in diameter (Fig. 5I), as in NHMLA 13497. Terminal or lateral exaulos tubes may extend out from cluster margins (Fig. 5I), or may extend into younger chambers, where overgrown, as cylindrical tubes that may be up to $2 \mathrm{~mm}$ in diameter, with interpores $0.6-0.7 \mathrm{~mm}$ in diameter. Conical exaulos basal walls may be up to $0.7-0.8 \mathrm{~mm}$ thick, around pores commonly $1.1-1.2 \mathrm{~mm}$ in diameter. These exaulos tubes may extend as isolated im- perforate tubes up to $2 \mathrm{~mm}$ long out from the main chamber walls (Fig. 5I), to where they may be $0.8-1.0 \mathrm{~mm}$ in diameter and $0.1-0.2 \mathrm{~mm}$ thick at their preserved tips, around pores $0.3-0.6 \mathrm{~mm}$ in diameter.

Material. - Three moderately large figured specimens, NHMLA 13496-13498, plus four larger fragments and eleven smaller fragments of the species, are in the studied collection from Locality LACMIP 24679. The samples were collected from a locality also later noted by Robert Elias et al. (1994).

Discussion. - Other species of the genus were also described by Rigby \& Potter (1986, pp. 28-32) from Ordovician occurrences in the Eastern Klamath Mountains, in northern California. These include Corymbospongia mica, which was differentiated because it has smaller-diameter chambers and exaulos tubes; and Corymbospongia(?) perforata, which also has smaller chambers than $C$. adnata, but is distinct because it also has coarsely porous exaulos tubes.

\section{Acknowledgments}

We appreciate the support of colleagues in the Department of Geological Sciences at Brigham Young University. Figures of the locality and stratigraphic information and photographic figures of the fossil sponges were prepared by Nicolle K. Anderson. Elise Robertson assisted in typing early versions of the manuscript. Both were students in the Department of Geological Sciences and employees of the Museum of Earth Science, Brigham Young University, at that time. We appreciate the helpful reviews of the manuscript by Matilde Beresi and Diego C. Garcia Bellido.

\section{References}

De Laubenfels, M.W. 1955. Porifera, E21-E1112. In Moore, R.C. (ed.) Treatise on Invertebrate Paleontology, Part E, Archaeocyatha and Porifera. Geological Society of America and University of Kansas Press, Lawrence.

DILLER, J.S. 1892. Geology of the Taylorsville region of California. Geological Society of America Bulletin 3, 369-394.

DILlER, J.S. 1908. Geology of the Taylorsville region, California. U.S. Geological Survey, Bulletin 353, 1-128.

EliAs, R.J., POTTER, A.W. \& WATKINS, R. 1994. Late Ordovician rugose corals of the northern Sierra Nevada, California. Journal of Paleontology, Paleontologic Notes 68(1), 164-168, figs 1-3.

FINKS, R.M. \& RiGBY, J.K. 2004. Hypercalcified sponges, E585-E758. In KAESLER, R.L. (ed.) Treatise on Invertebrate Paleontology, pt. E, Porifera (revised). Volume 3. Geological Society of America \& The University of Kansas Press, Denver \& Lawrence. 
LÉVI, C.L. 1953. Sur un nouvelle classification des Démosponges. Comptes rendus des séances de l'Académie des Sciences, Série D 236, 853-855.

MCMATH, W.E. 1958. The geology of the Taylorsville area, Plumas County, California. 199 pp. Unpublished Ph.D. dissertation, University of California, Los Angeles.

POTTER, A.W., WATKINS, R., BOUCOT, A.J., EliAs, R.J., FlORY, R.A. \& RigBY, J.K. 1990. Biogeography of the Upper Ordovician Montgomery Limestone, Shoo Fly Complex, northern Sierra Nevada, California and comparisons of the Shoo Fly Complex and Yreka terrane, 33-41. In HARWOOD, D.W. \& MILLER, M.M. (eds) Paleozoic and Early Mesozoic paleogeographic relations; Sierra Nevada, Klamath Mountains, and Related Terranes. Geological Society of America Special Paper 255.

RigBY, J.K., KARL, S.M., BLODGETT, R.B. \& BAICHTAL, J.E. 2005. Ordovician "sphinctozoan" sponges from Prince of Wales Island, southeastern Alaska. Journal of Paleontology 79, 862-870. DOI 10.1666/0022-3360(2005)079[0862:OSSFPO]2.0.CO;2

RigBY, J.K. \& POTTER, A.W. 1986. Ordovician sphinctozoan sponges from the eastern Klamath Mountains, northern California. Paleontological Society Memoir 20, Journal of Paleontology, 60,1-47, supplement.

SenOwbari-Daryan, B. 1990. Die systematische Stellung der thalamiden Schwämme und ihrer bedeutung in der Erdgeschichte. Münchner Geowissenschaftliche Abhandlungen (Reihe A, Geologie und Paläontologie) 21, 1-325, pls 121-63.
SenOwbari-Daryan, B. \& Rigby, J.K. 1988. Upper Permian segmented sponges from Djebel Tebaga, Tunisia. Facies 19, 171-250, 15 figs, pls 22-40.

SOLLAS, W.J. 1875. Sponges, 427-446. In Encyclopaedia Britannica $\left(9^{\text {th }}\right.$ edition). Adam \& Charles Black, Edinburgh.

SteInMAnN, G. 1882. Pharetronen-Studien. Neues Jahrbuch für Mineralogie, Geologie und Palaeontologie 2, 139-191, pls 6-9.

STOCK, C.W. 1981. Cliefdenella alaskaensis n. sp. (Stromatoporoidea) from the Middle/Upper Ordovician of central Alaska. Journal of Paleontology 55(5), 998-1005.

VERRILL, A.E. 1907. Porifera of the Bermuda Islands. Transactions of the Academy of Arts and Sciences 12, 330-344.

WeBBy, B.D. 1969. Ordovician stromatoporoids from New South Wales. Palaeontology 12, 737-662.

WeBBy, B.D. 1986. Early Stromatoporoids, 148-166. In HoFFMAN, A. \& NITECKI, M. (eds) Problematic Fossil Taxa, Chapter 12. Oxford University Press.

WEBBY, B.D. \& LIN BAYOU 1988. Upper Ordovician cliefdenellids (Porifera: Sphinctozoa) from China. Geological Magazine 125(2), 149-159.

WEBBY, B.D. \&. MORRIS, D.G. 1976. New Ordovician stromatoporoids from New South Wales. Royal Society of New South Wales, Journal and Proceedings 109, 125-135.

WebBy, B.D. \& RigBY, J.K. 1985. Ordovician sphinctozoan sponges from New South Wales. Alcheringa 9, 209-220, 10 text-figs. 